\title{
Systemic sclerosis - diagnostic and therapeutic recommendations of the Polish Dermatological Society. Part I: diagnosis and monitoring
}

\author{
Twardzina układowa - rekomendacje diagnostyczno-terapeutyczne Polskiego \\ Towarzystwa Dermatologicznego. Część I: diagnostyka i monitorowanie
}

Dorota Krasowska', Lidia Rudnicka², Aleksandra Dańczak-Pazdrowska ${ }^{3}$, Grażyna Chodorowska4 ${ }^{4}$ Anna Woźniacka ${ }^{5}$, Anna Lis-Święty ${ }^{6}$, Joanna Czuwara ${ }^{2}$, Joanna Maj ${ }^{7}$, Sławomir Majewski ${ }^{8}$, Anna Sysa-Jędrzejowska', Anna Wojas-Pelc ${ }^{10}$

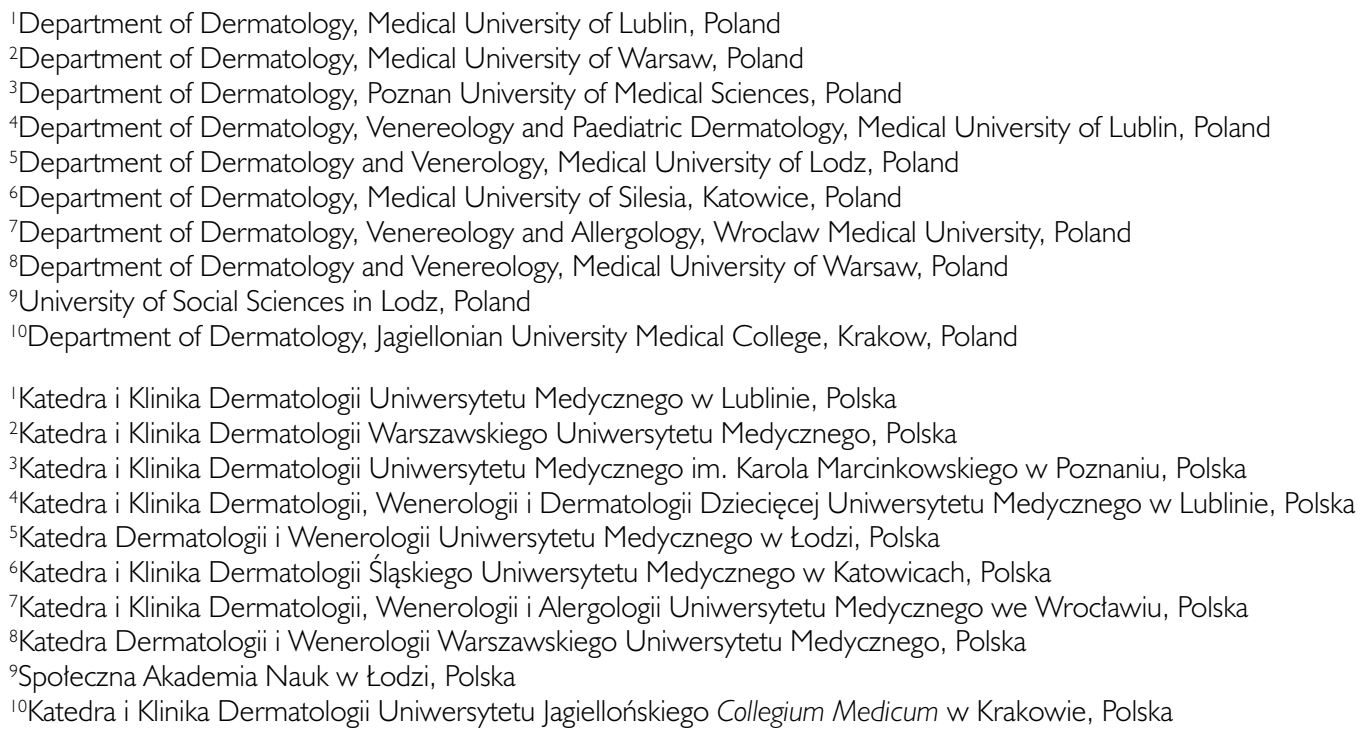

\section{CORRESPONDING AUTHOR/} ADRES DO KORESPONDENCJI: prof. dr hab. n. med. Dorota Krasowska Katedra i Klinika Dermatologii Uniwersytet Medyczny w Lublinie ul. Radziwiłłowska 13 20-080 Lublin tel.: +48608098578 faks: +48 815323647 e-mail: dorota.krasowska@umlub.pl

\begin{abstract}
Systemic sclerosis is an immune-mediated disease characterized by a chronic and progressive course. It often leads to multiorgan failure and patient disability, and contributes to significant reduction in the quality of life. Systemic sclerosis affects the skin, subcutaneous tissue, muscles, osteoarticular system and internal organs. The complexity and diversity of clinical presentations require an individual approach and multidisciplinary collaboration both at the stage of diagnosis and treatment. Critical factors in systemic sclerosis include early diagnosis, assessment of internal organ involvement, identification of patients at potential risk of organ complications, assessment of disease dynamics and activity, and implementation of optimal therapy. Part 1 presents current recommendations for the diagnostics and monitoring of patients with systemic sclerosis. Attention is given to classification criteria, clinical forms of systemic sclerosis, assessment of skin thickness and systemic sclerosis microangiopathy, significance of antinuclear antibodies, diagnosis of interstitial lung disease and pulmonary arterial hypertension, renal crisis and cardiac abnormalities, and evaluation of the gastrointestinal tract and osteoarticular and muscular systems.
\end{abstract}




\section{STRESZCZENIE}

Twardzina układowa jest chorobą mediowaną immunologicznie o przewlekłym i postępującym przebiegu. Często prowadzi do niewydolności wielonarządowej, niepełnosprawności chorych i przyczynia się do znacznego obniżenia jakości życia. Procesem chorobowym zajęta jest skóra, tkanka podskórna, mięśnie, układ kostno-stawowy oraz narządy wewnętrzne. Złożony i zróżnicowany obraz kliniczny chorych wymaga indywidualnego podejścia i współpracy wielospecjalistycznej zarówno na etapie diagnozowania, jak i leczenia chorych. W twardzinie układowej ważne są wczesne rozpoznanie, ocena zajęcia procesem chorobowym narządów wewnętrznych, identyfikacja chorych z ryzykiem wystąpienia powikłań narządowych, ocena dynamiki i aktywności choroby i wdrożenie optymalnej terapii. W części pierwszej przedstawiono aktualne rekomendacje dotyczące rozpoznawania, diagnostyki i monitorowania chorych. Omówiono kryteria klasyfikacyjne, postacie kliniczne twardziny układowej, ocenę grubości fałdu skórnego, mikroangiopatię twardzinową, znaczenie przeciwciał jądrowych, diagnostykę choroby śródmiąższowej płuc i tętniczego nadciśnienia płucnego, przełomu nerkowego, diagnostykę zmian w sercu, ocenę przewodu pokarmowego oraz zmian w układzie kostno-stawowo-mięśniowym.

Key words: systemic sclerosis, guidelines, diagnostics, monitoring.

Słowa kluczowe: twardzina układowa, rekomendacje, diagnostyka, monitorowanie.

\section{INTRODUCTION}

Systemic sclerosis (SSc) is an immune-mediated disease with a chronic progressive course leading to multiorgan failure and patient disability, and contributing to significant impairment in the quality of life [1]. The disease process involves the skin, subcutaneous tissue, muscles, osteoarticular system and internal organs. The development of the disease depends on a number of factors including abnormalities in the morphology and function of small blood vessels, presence of inflammation, immune disorders and excessive collagen synthesis contributing to the fibrosis of the skin and internal organs. The complex and diverse clinical features seen in patients require case-by-case approach and cooperation of multiple specialists both at the stage of diagnosis and treatment. Critical factors in SSc include early diagnosis, assessment of internal organ involvement, identification of patients at potential risk of organ complications, assessment of disease dynamics and activity, and implementation of optimal therapy [2, 3]. The study presents current recommendations for the diagnostics and monitoring of patients.

\section{DIAGNOSIS}

The classification criteria for SSc have been repeatedly revised. The 1980 classification criteria for

\section{WPROWADZENIE}

Twardzina układowa (systemic sclerosis - SSc) jest chorobą mediowaną immunologicznie o przewlekłym, postępującym przebiegu. Prowadzi do niewydolności wielonarządowej, niepełnosprawności chorych i przyczynia się do znacznego obniżenia jakości życia [1]. Procesem chorobowym zajęta jest skóra, tkanka podskórna, mięśnie, układ kostno-stawowy oraz narządy wewnętrzne. W rozwoju choroby ważną rolę odgrywają zaburzenia morfologii i funkcji drobnych naczyń krwionośnych, obecność procesu zapalnego, zaburzenia immunologiczne oraz nadmierna synteza kolagenu przyczyniająca się do włóknienia skóry i narządów wewnętrznych. Złożony i zróżnicowany obraz kliniczny wymaga indywidualnego podejścia i współpracy wielospecjalistycznej zarówno na etapie diagnozowania, jak i leczenia chorych. W SSc ważne są wczesne rozpoznanie, ocena zajęcia procesem chorobowym narządów wewnętrznych, identyfikacja chorych z ryzykiem wystąpienia powikłań narządowych, ocena dynamiki i aktywności choroby oraz wdrożenie optymalnej terapii $[2,3]$. W pracy przedstawiono aktualne rekomendacje dotyczące rozpoznawania, diagnostyki i monitorowania chorych.

\section{ROZPOZNANIE CHOROBY}

Kryteria klasyfikacji SSc były wielokrotnie modyfikowane. Przez wiele lat posługiwano się kryteria- 
SSc were applied for many years [4]. The main shortcoming was their low sensitivity in patients with limited cutaneous SSc (lcSSc) and early forms of the disease [5, 6]. In 2001, LeRoy and Medsger proposed diagnostic criteria for early SSc which included Raynaud's phenomenon, nailfold capillaroscopy changes and presence of SSc-specific autoantibodies [7]. In 2014, the so-called puffy fingers - in combination with the above - were indicated as "red flags" and included as symptoms of very early diagnosis of SSc (VEDOSS) $[8,9]$. Preliminary results of the prospective trial VEDOSS show that the positive predictive value for systemic sclerosis in patients presenting with Raynaud's phenomenon, puffy fingers turn- mi z 1980 r. [4]. Ich główną wadą była mała czułość w przypadku chorych na SSc z ograniczonymi stwardnieniami skóry (limited cutaneous SSc-1cSSc) oraz wczesnych postaci choroby [5, 6]. W 2001 r. LeRoy i Medsger zaproponowali kryteria rozpoznania wczesnej SSc, które obejmowały obecność objawu Raynauda, zmiany w obrazie kapilaroskopowym wałów paznokciowych oraz obecność autoprzeciwciał swoistych dla SSc [7]. W 2014 r. tzw. obrzęnnięte palce (puffy fingers) w połączeniu z ww. cechami nazwano „czerwonymi flagami” i zaliczono do objawów wczesnej SSc (very early diagnosis of SSc - VEDOSS) [8,9]. Wstępne wyniki prospektywnego badania VEDOSS wykazały, że dodatnia wartość predykcyjna dla SSc u chorych

Table I. EULAR/ACR classification criteria (2013)

\begin{tabular}{|c|c|c|}
\hline Item & Sub-item & Score \\
\hline \multicolumn{2}{|l|}{$\begin{array}{l}\text { skin thickening of the fingers of both hands extending proximally } \\
\text { from the MCP joints }\end{array}$} & 9 \\
\hline skin thickening of the fingers & $\begin{array}{l}\text { - } \text { puffy fingers } \\
\text { - sclerodactyly (distal to the MCP joints } \\
\text { but proximal to the PIP joints) }\end{array}$ & $\begin{array}{l}2 \\
4\end{array}$ \\
\hline fingertip lesions & $\begin{array}{l}\text { - ulcers } \\
\text { - scars } \\
\end{array}$ & $\begin{array}{l}2 \\
3 \\
\end{array}$ \\
\hline telangiectasias & - & 2 \\
\hline abnormal nailfold capillaries & - & 2 \\
\hline pulmonary arterial hypertension and/or interstitial lung disease & $\begin{array}{l}\text { - pulmonary arterial hypertension } \\
\text { - interstitial lung disease }\end{array}$ & $\begin{array}{l}2 \\
2\end{array}$ \\
\hline Raynaud's phenomenon & - & 3 \\
\hline SSc-related autoantibodies (ACA, Scl-70, RNAP III) & - & 3 \\
\hline \multicolumn{3}{|c|}{$\begin{array}{l}\text { MCP - metacarpophalangeal, PIP - proximal interphalangeal, ACA - anti-centromere antibodies, Scl-70 - antibodies against topoisomerase I, RNAP III - anti- } \\
\text { bodies against RNA polymerase III. The criteria are not applicable to patients without skin lesions involving the fingers or patients whose clinical presentation } \\
\text { suggests a scleroderma-like disorder (e.g. nephrogenic systemic fibrosis, generalized morphea, eosinophilic fasciitis, indurated oedema, scleromyxedema, erythro- } \\
\text { myalgia, porphyria, lichen sclerosus, graft-versus-host disease, diabetic cheiroarthropathy). Interpretation: the total score is determined by adding the maximum } \\
\text { score in each category. To diagnose systemic sclerosis, the score must be } \geq 9 \text { (which means that the first item is the sufficient criterion). }\end{array}$} \\
\hline
\end{tabular}

Tabela I. Kryteria klasyfikacyjne EULAR/ACR z 2013 r.

\begin{tabular}{|c|c|c|}
\hline Kategoria objawu & Podtyp & Punktacja \\
\hline pogrubienie skóry proksymalnie do MIP, obustronne & - & 9 \\
\hline pogrubienie skóry palców & $\begin{array}{l}\text { - obrzęknięte palce } \\
\text { - sklerodaktylia (dystalnie do MIP, } \\
\text { ale proksymalnie do PIP) }\end{array}$ & $\begin{array}{l}2 \\
4\end{array}$ \\
\hline zmiany na opuszkach palców & $\begin{array}{l}\text { - owrzodzenia } \\
\text { - blizny }\end{array}$ & $\begin{array}{l}2 \\
3 \\
\end{array}$ \\
\hline teleangiektazje & - & 2 \\
\hline zmiany w kapilaroskopii & - & 2 \\
\hline płucne nadciśnienie tętnicze i/lub śródmiąższowa choroba płuc & $\begin{array}{l}\text { - płucne nadciśnienie tętnicze } \\
\text { - śródmiąższowa choroba płuc }\end{array}$ & $\begin{array}{l}2 \\
2\end{array}$ \\
\hline objaw Raynauda & - & 3 \\
\hline $\begin{array}{l}\text { autoprzeciwciała swoiste dla twardziny układowej } \\
\text { (ACA, Scl-70, RNAP III) }\end{array}$ & - & 3 \\
\hline
\end{tabular}

MIP - stawy śródręczno-paliczkowe, PIP - proksymalne stawy międzypaliczkowe, ACA - przeciwciała antycentromerowe, Scl-70 - przeciwciała przeciwko topoizomerazie I, RNAP III - przeciwciała przeciwko polimerazie III RNA. Powyższych kryteriów nie należy stosować u osób, u których nie stwierdza się zmian w obrębie skóry palców rąk, oraz u tych, u których obraz kliniczny sugeruje rozpoznanie z kręgu chorób twardzinopodobnych (np. nerkopochodne włóknienie układowe, postać uogólniona morphea, eozynofilowe zapalenie powięzi, obrzęk stwardniaty, scleromyxedema, erythromyalgia, porfiria, liszaj twardzinowy, choroba przeszczep przeciwko gospodarzowi, cheiroartropatia cukrzycowa). Interpretacja: całkowitą punktację uzyskuje się, dodając maksymalnq liczbę punktów z poszczególnych kategorii. Aby rozpoznać twardzinę układowq, należy uzyskać $\geq 9$ punktów (co oznacza, że pierwsze kryterium jest kryterium wystarczajq̨cym). 
ing to sclerodactyly and specific autoantibodies is 88.5\% [10]. In 2013, the European League Against Rheumatism (EULAR) and the American College of Rheumatology (ACR) proposed the most recent classification criteria prepared by expert teams, which are currently recommended (Table 1) [11]. The criteria were validated, and shown to have sensitivity of $91 \%$ and specificity of $92 \%$. A study comparing the sensitivity of available criteria in early forms of the disease demonstrated that the 2013 criteria made diagnosis possible in $79.6 \%$ of patients, compared to just $53.3 \%$ of patients diagnosed on the basis of the 1980 criteria [12-14]. The clinical picture in SSc may vary in different patients and represents an important prognostic factor. Several forms of the disease have been distinguished (Table 2). Diffuse cutaneous systemic sclerosis (dcSSc) is characterized by the most rapid course with internal organ involvement already at early disease stage, and severe prognosis [15]. Skin thickening confined to sites above the el- z objawem Raynauda, obrzękniętymi palcami ewoluującymi w kierunku sklerodaktylii i obecnością swoistych autoprzeciwciał wynosi 88,5\% [10]. W 2013 r. przedstawiono najnowsze i obecnie rekomendowane kryteria klasyfikacyjne przygotowane przez zespół ekspertów Europejskiej Ligii do Walki z Reumatyzmem (European League Against Rheumatism - EULAR) i Amerykańskiego Kolegium Reumatologicznego (American College of Rheumatology - ACR) (tab. 1) [11]. Kryteria te poddano walidacji i ich czułość wynosi $91 \%$, a swoistość $92 \%$. W badaniu, w którym porównywano czułość kryteriów w przypadku wczesnych postaci choroby, za pomocą kryteriów z 2013 r. chorobę rozpoznano u 79,6\% pacjentów, a za pomocą kryteriów z 1980 r. - jedynie u 53,3\% [12-14]. Obraz kliniczny SSc może się różnić u poszczególnych chorych i stanowi ważny czynnik rokowniczy. Wyróżniono kilka odmian choroby (tab. 2). Twardzina układowa z uogólnionymi stwardnieniami skóry (diffuse cutaneous systemic sclerosis - dcSSc) cechu-

Table 2. Clinical forms of systemic sclerosis

\begin{tabular}{|c|c|}
\hline Form & Characteristic clinical features \\
\hline $\begin{array}{l}\text { limited cutaneous } \\
\text { systemic sclerosis } \\
\text { (IsSSc) }\end{array}$ & $\begin{array}{l}\text { - Raynaud's phenomenon preceding the onset of other disease manifestations by many years } \\
\text { - skin lesions confined to acral locations (distal to elbow/knee joints) } \\
\text { - slow disease course with clinical manifestations of internal organ involvement emerging at a later disease stage } \\
\text { - high risk of pulmonary arterial hypertension, gastrointestinal tract fibrosis }\end{array}$ \\
\hline $\begin{array}{l}\text { diffuse cutaneous } \\
\text { systemic sclerosis } \\
\text { (dcSSc) }\end{array}$ & $\begin{array}{l}\text { - Raynaud's phenomenon developing shortly before other disease manifestations } \\
\text { - skin lesions additionally involving proximal extremities and the trunk } \\
\text { - aggressive disease course with rapidly progressing fibrosis of internal organs } \\
\text { - high risk of renal crisis, severe lung fibrosis and cardiac complications }\end{array}$ \\
\hline $\begin{array}{l}\text { systemic sclerosis } \\
\text { sine scleroderma }\end{array}$ & $\begin{array}{l}\text { absence of skin thickening in the presence of other diagnostic criteria such as Raynaud's phenomenon, typical } \\
\text { serological and capillaroscopic findings, internal organ manifestations; may occur in cases of very early systemic } \\
\text { sclerosis }\end{array}$ \\
\hline $\begin{array}{l}\text { systemic sclerosis } \\
\text { overlap syndrome }\end{array}$ & $\begin{array}{l}\text { laboratory and clinical features of other connective tissue disorders (rheumatoid arthritis, systemic lupus } \\
\text { erythomatosus, polymyositis) }\end{array}$ \\
\hline
\end{tabular}

Tabela 2. Postacie kliniczne twardziny układowej

\begin{tabular}{|c|c|}
\hline Postać & Charakterystyczne cechy kliniczne \\
\hline $\begin{array}{l}\text { twardzina } \\
\text { uogólniona } \\
\text { z ograniczonymi } \\
\text { stwardnieniami } \\
\text { skóry }(\text { IcSSc) }\end{array}$ & $\begin{array}{l}\text { - objaw Raynauda wyprzedzający o wiele lat wystąpienie innych cech choroby } \\
\text { - zmiany skórne ograniczone do lokalizacji akralnych (dystalnie do stawów łokciowych lub kolanowych) } \\
\text { - powolny przebieg choroby z klinicznymi cechami zajęcia narządów wewnętrznych pojawiającymi się } \\
\text { - w późniejszej fazie choroby }\end{array}$ \\
\hline $\begin{array}{l}\text { twardzina } \\
\text { uogólniona } \\
\text { z uogólnionymi } \\
\text { stwardnieniami } \\
\text { skóry (dcSSc) }\end{array}$ & $\begin{array}{l}\text { - objaw Raynauda pojawiający się krótko przed innymi objawami choroby } \\
\text { - zmiany skórne obejmują dodatkowo proksymalne odcinki kończyn i tułów } \\
\text { - agresywny przebieg choroby z szybko postępującym włóknieniem narządów wewnętrznych } \\
\text { - duże ryzyko przełomu nerkowego, ciężkiego włóknienia płuc, powikłań kardiologicznych }\end{array}$ \\
\hline $\begin{array}{l}\text { twardzina układowa } \\
\text { bez zajęcia skóry }\end{array}$ & $\begin{array}{l}\text { brak stwardnienia skóry przy spełnianiu innych kryteriów rozpoznania, takich jak występowanie objawu } \\
\text { Raynauda, typowych cech serologicznych i kapilaroskopowych, objawów ze strony narządów wewnętrznych; } \\
\text { może dotyczyć przypadków bardzo wczesnej twardziny układowej }\end{array}$ \\
\hline $\begin{array}{l}\text { twardzina układowa } \\
\text { w zespołach } \\
\text { nakładania }\end{array}$ & $\begin{array}{l}\text { obecność laboratoryjnych i klinicznych cech innych chorób tkanki łącznej (reumatoidalne zapalenie stawów, } \\
\text { toczeń układowy, zapalenie wielomięśniowe) }\end{array}$ \\
\hline
\end{tabular}


bows or knees is classified as lcSSc. It is important to note that approximately $20 \%$ of patients with lcSSc may present with features of SSc as a component of the overlap syndrome $[16,17]$.

The severity of skin lesions is assessed using modified Rodnan Skin Score (mRSS) which is based on the measurement of skin thickness in 17 body sites: face (between the zygomatic bones and mandible), forearms and arms (external surfaces), fingers of both hands (dorsal surfaces of proximal and intermediate phalanges), hands (dorsal surfaces), chest (skin area from the manubrial notch to the xiphoid, breast regions), abdomen (area between the extensions of midaxillary lines from the xiphoid to the pubic symphysis, particularly between the xiphoid and the navel line), calves and thighs (anterior surfaces), and feet (dorsal surfaces from the metatarsophalangeal joints as far as the anterior surface of the tarsal joint). Skin thickening is assessed using a 0-4 scale: 0 - normal skin, 1 mild thickness, 2 - moderate thickness, 3 - severe thickness. The sum of individual measured values is defined as the total skin score which ranges from 0 (no change) to maximum 51 (severe skin thickening in all 17 sites) [18]. Rodnan's score is a good indicator of both improvement and disease progression, not only with respect to the severity of skin lesions but also organ abnormalities [19, 20]. The method of calculating the mRSS score is shown in detail in Figure 1. je się najbardziej dynamicznym przebiegiem, z zajęciem narządów wewnętrznych już we wczesnym okresie i poważnym rokowaniem [15]. Granica stwardnień do stawu łokciowego lub kolanowego kwalifikuje chorobę jako ograniczoną (lcSSc). Należy zauważyć, że ok. $20 \%$ chorych na lcSSc może mieć cechy SSc jako jeden z elementów zespołu nakładania $[16,17]$.

Nasilenie zmian skórnych ocenia się za pomocą zmodyfikowanej skali Rodnana (modified Rodnan Skin Score - mRSS), na podstawie badania grubości fałdu skórnego w 17 lokalizacjach anatomicznych: twarz (między kością jarzmową a żuchwą), przedramiona i ramiona (zewnętrzna powierzchnia ramienia i przedramienia), palce obu rąk (grzbietowe obszary proksymalnych i środkowych paliczków), ręce (grzbietowe powierzchnie rąk), klatka piersiowa (obszar skóry od cięcia jarzmowego mostka po wyrostek mieczykowaty, okolice sutkowe), brzuch (obszar między przedłużeniami linii pachowych pośrodkowych od wyrostka mieczykowatego po spojenie łonowe, zwłaszcza między wyrostkiem mieczykowatym a linią pępa), podudzie i uda (przednia powierzchnia konczyn), stopy (powierzchnie grzbietowe od stawów śródstopno-paliczkowych po przednią powierzchnię stawu skokowego). Grubość fałdu skórnego (thickening) ocenia się w 4-stopniowej skali: 0 - prawidłowa grubość, 1 - niewielkie zgrubienie, 2 - wyraźnie pogrubiały fałd, 3 - bardzo pogrubiały fałd skórny. Suma wszystkich pomiarów jest ostatecznym wynikiem i może wynosić od 0 (brak zmian) do maksymalnie 51

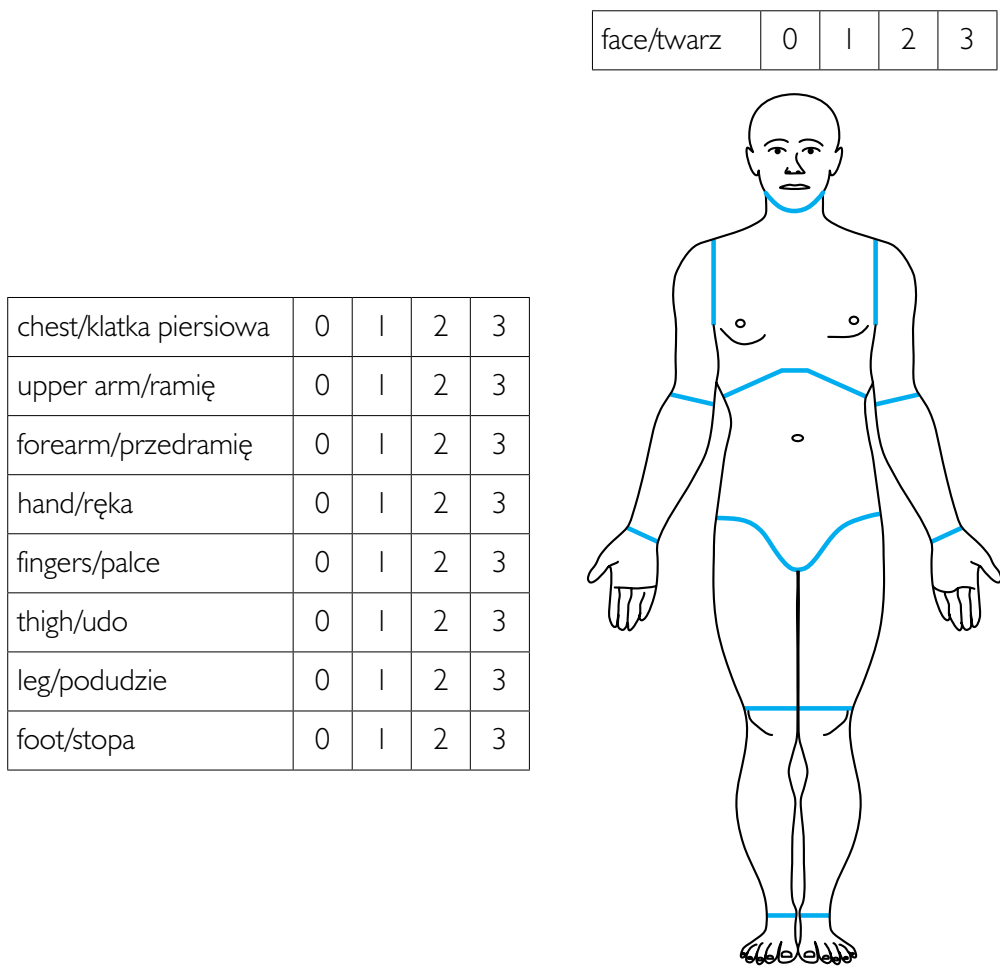

\begin{tabular}{|l|c|c|c|c|}
\hline abdomen/brzuch & 0 & । & 2 & 3 \\
\hline upper arm/ramię & 0 & । & 2 & 3 \\
\hline forearm/przedramię & 0 & । & 2 & 3 \\
\hline hand/ręka & 0 & । & 2 & 3 \\
\hline fingers/palce & 0 & । & 2 & 3 \\
\hline thigh/udo & 0 & । & 2 & 3 \\
\hline leg/podudzie & 0 & । & 2 & 3 \\
\hline foot/stopa & 0 & । & 2 & 3 \\
\hline
\end{tabular}

Figure I. Evaluation of skin thickness in the mRSS

Rycina I. Schemat oceny grubości fałdu skórnego w mRSS 


\section{LABORATORY AND DIAGNOSTIC TESTS}

Since there are no drugs that would significantly reverse the process of fibrosis, early diagnosis is a factor determining patient outcome. As the first step, evaluation of disease activity and appropriate classification should be performed. Further tests should be carried out to periodically assess disease stage in different organs. Although there is no consensus between experts as to the required frequency of tests in individuals presenting with the so-called "red flags", it needs to be noted that subclinical involvement of internal organs occurs already at the earliest disease stages [21]. Laboratory tests and their frequencies recommended by the Polish Dermatological Society are listed in Table 3. (skóra bardzo pogrubiała we wszystkich 17 obszarach) [18]. Wskaźnik Rodnana jest dobrym wykładnikiem zarówno poprawy, jak i progresji choroby w zakresie nasilenia zmian nie tylko skórnych, lecz także narządowych [19, 20]. Szczegółowe zasady obliczenia mRSS przedstawiono na rycinie 1 .

\section{BADANIA LABORATORYJNE I DIAGNOSTYCZNE}

Ze względu na brak leków istotnie odwracających proces włóknienia wczesne rozpoznanie stanowi czynnik decydujący o dalszym losie chorego. Pierwszym elementem jest wykonanie badań oceniających aktywność choroby i umożliwiających właściwe jej zakwalifikowanie. Kolejne badania służą okresowej ocenie

Table 3. Examinations recommended prior to establishing the diagnosis of systemic sclerosis and for monitoring the course of systemic scleroderma, along with their recommended frequencies

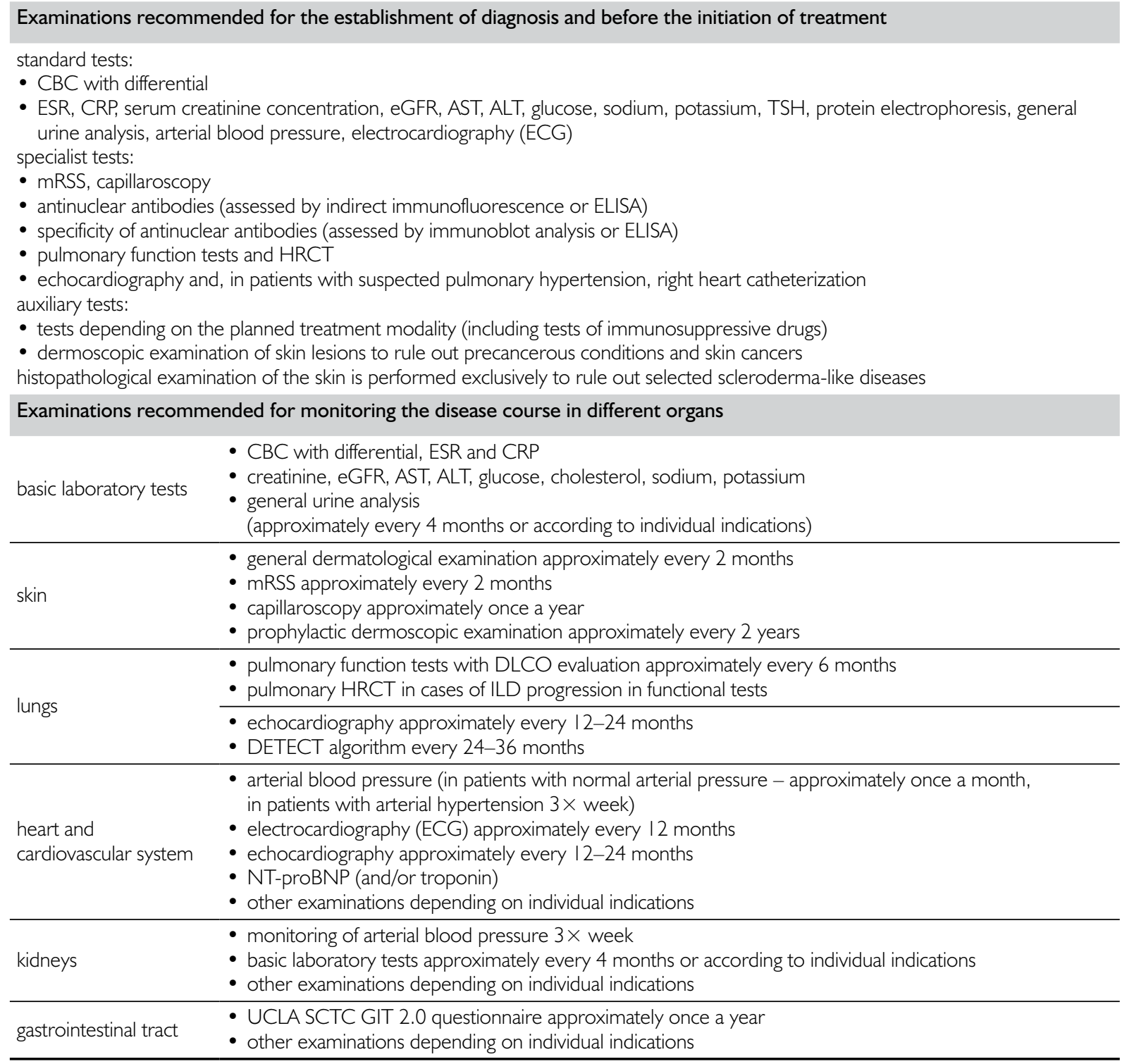




\section{CAPILLAROSCOPY (EVALUATION OF SCLERODERMA PATTERN OF MICROANGIOPATHY)}

One of the earliest manifestations of the disease, often preceding the development of other features of systemic sclerosis by several years, is Raynaud's phenomenon, i.e. triphasic change in skin colour affecting primarily fingers and toes. Raynaud's phenomenon occurs in over $95 \%$ of patients [22], and its presence is an indication for nailfold capillaroscopy. Capillaroscopic examination is a non-invasive and painless technique for evaluating the number, shape and size of blood vessels in the nailfold microcirculation as well as other features of damage zaawansowania choroby w poszczególnych narządach. Nie ma zgodności między ekspertami, jak często należy wykonywać badania u osób z tzw. red flags. Należy jednak zauważyć, że już w najwcześniejszych etapach choroby dochodzi do subklinicznego zajęcia narządów wewnętrznych [21]. Badania laboratoryjne zalecane przez Polskie Towarzystwo Dermatologiczne i częstość ich wykonywania przedstawiono w tabeli 3.

\section{BADANIE KAPILAROSKOPOWE (OCENA MIKROANGIOPATII TWARDZINOWEJ)}

Jednym z najwcześniejszych symptomów choroby, który niejednokrotnie wyprzedza pojawienie się innych cech SSc nawet o kilka lat, jest objaw Raynau-

Tabela 3. Badania zalecane przed ustaleniem rozpoznania twardziny układowej i w celu monitorowania jej przebiegu oraz rekomendowana częstość ich wykonywania




including micro-petechiae. Normal capillaries have an inverted U-shape which consists of arterial (ascending) limb with a width of 6-19 $\mu \mathrm{m}$, apex, and venous (descending) limb with a width of $8-20 \mu \mathrm{m}$. The venous limb width to arterial limb width ratio should not be greater than $2: 1$. In healthy individuals the capillaries are arranged regularly, in parallel to one another and perpendicularly to the eponychium. They are approximately $300 \mu \mathrm{m}$ (200-500 $\mu \mathrm{m})$ long. The capillary density ranges from 9 to 13 per $1 \mathrm{~mm}$ (1-3 capillary loops/ 1 dermal papilla). Common findings seen in patients with SSc include enlarged capillaries and so-called megacapillaries, microextravasations, reduced capillary density, features of angiogenesis and stromal oedema. Megacapillaries (capillaries with a diameter greater than $50 \mu \mathrm{m}$ ) appear already in the earliest stages of the disease. Consequently, even one identified megacapillary may raise the suspicion of systemic sclerosis. In the classic approach, however, the presence of two megacapillaries is to be recognized as a diagnostic criterion for the scleroderma pattern of microangiopathy. The next stage involves microextravasations, typically taking the form of cap-shaped petechiae. Ultimately, the capillary density decreases, and avascular areas are formed. A reduction in the number of capillaries below 30 per $5 \mathrm{~mm}$ is thought to be highly specific to SSc. Angiogenesis is manifested as the presence of ramified/bushy capillaries which are often located in the immediate vicinity of avascular areas [23, 24]. At present, the most commonly recommended classification of capillaroscopy findings in SSc is that proposed by Cutolo et al., which is based on three patterns: early, active, and late [25]. The early subtype is associated with isolated megacapillaries and petechiae, with normal capillary density and relatively well-preserved capillary configuration. The active stage is characterized by multiple megacapillaries and petechiae, and moderate (20-30\%) reduction in capillary density accompanied by mildly disorganized arrangement of capillary vessels. No bushy capillaries are observed at this stage. The late pattern is identified when the features are dominated by a dramatic (50-70\%) decrease in capillary density with avascular areas and complete disorganization of the normal capillary array with the presence of ramified/bushy capillaries. Severe abnormalities seen on capillaroscopy are correlated with the stage of the disease both with respect to skin and organ lesions, and may have a prognostic significance [26-28]. Sebastiani et al. proposed the capillaroscopic skin ulcer risk index (CSURI) expressed with the formula $M \times D: N^{2}$, where $M$ is the number of megacapillaries in $1 \mathrm{~mm}, D$ - the largest megacapillary dimension (with the exception of microaneu- da, czyli trójfazowa zmiana barwy skóry, najczęściej palców rąk i stóp. Występuje on u ponad 95\% chorych [22], a jego obecność wskazuje na konieczność wykonania oceny mikrokrążenia wałów paznokciowych. Badanie kapilaroskopowe pozwala na nieinwazyjną i niebolesną ocenę kształtu, wielkości i liczby naczyń mikrokrążenia wału paznokciowego oraz dodatkowych cech ich uszkodzenia, np. mikrowybroczyn. Prawidłowe naczynia włosowate mają kształt odwróconej litery U, na którą składa się: ramię tętnicze (wstępujące) o szerokości 6-19 $\mu \mathrm{m}$, część szczytowa i ramię żylne (zstępujące) - 8-20 $\mu \mathrm{m}$. Stosunek szerokości ramienia zstępującego do wstępującego nie powinien przekraczać 2 : 1 . U osób zdrowych naczynia rozmieszczone są regularnie, równolegle względem siebie i prostopadle do linii obrąbka naskórkowego. Ich długość wynosi ok. $300 \mu \mathrm{m}(200-500 \mu \mathrm{m})$. Gęstość naczyń waha się od 9 do 13 w $1 \mathrm{~mm}$ (1-3 pętle naczyniowe w brodawce skórnej). U chorych na SSc można obserwować naczynia powiększone i tzw. megakapilary, mikrowynaczynienia, zmniejszoną gęstość naczyń, cechy angiogenezy oraz obrzęk podścieliska. Megakapilary (naczynia, których szerokość przekracza $50 \mu \mathrm{m}$ ) pojawiają się w najwcześniejszych etapach choroby i wykrycie choćby jednej może budzić podejrzenie SSc. Klasycznie jednak przyjmuje się, że obecność 2 megakapilar powinna stanowić kryterium rozpoznania mikroangiopatii twardzinowej. W kolejnym etapie pojawiają się mikrowynaczynienia, najczęściej o morfologii wybroczyn czapeczkowatych, a ostatecznie dochodzi do zmniejszenia gęstości kapilar i pojawienia się pól awaskularnych. Sugeruje się, że zmniejszenie liczby kapilar poniżej 30 na obszarze $5 \mathrm{~mm}$ jest zjawiskiem wysoce swoistym dla SSc. Angiogeneza objawia się obecnością naczyń rozgałęzionych lub drzewkowatych, często zlokalizowanych w bezpośrednim sąsiedztwie pól awaskularnych [23, 24]. Obecnie najczęściej zalecana jest klasyfikacja obrazu kapilaroskopowego zaproponowana przez Cutolo i wsp. Wyróżnia ona trzy wzory obrazu: wczesny, aktywny i późny [25]. W podtypie wczesnym obserwuje się pojedyncze megakapilary i wybroczyny, przy prawidłowej gęstości i dość dobrze zachowanej organizacji układu naczyń. Faza aktywna cechuje się obecnością licznych megakapilar i wybroczyn, umiarkowanym (20-30\%) zmniejszeniem gęstości naczyń z towarzyszącą nieznaczną dezorganizacją ich układu. Nie stwierdza się w tej fazie kapilar drzewkowatych. Wzór późny rozpoznaje się, gdy w obrazie przeważa dramatyczne (50-70\%) zmniejszenie gęstości naczyń z obecnością pól awaskularnych i całkowitą dezorganizacją układu kapilar, które mają charakter naczyń rozgałęzionych i drzewkowatych. Nasilenie zmian w obrazie kapilaroskopowym koreluje ze stopniem zaawansowania choroby zarówno w zakresie zmian skórnych, jak i narządowych oraz może mieć znaczenie prognostyczne [26-28]. Sebastiani i wsp. zaproponowali kapilarosko- 
rysmal dilations) and $N$ - the number of capillary loops in $1 \mathrm{~mm}$. The cut-off point is 2.96. Patients with higher CSURI values had a significantly higher risk of digital ulcers during a period of 3 months after examination [29]. The examination is performed using a capillaroscope dedicated to the assessment of blood vessels in the nailfold microcirculation. In exceptional cases (preliminary) capillaroscopy can be performed with a manual dermatoscope.

\section{ANTINUCLEAR ANTIBODIES}

Antinuclear antibodies (ANA) are detected in 90-95\% of all patients with SSc. Patients with diffuse scleroderma but without circulating antinuclear antibodies require thorough differential diagnostics to rule out scleroderma-like diseases [30]. Patients usually present with only one disease-specific autoantibody. Therefore, the type of antibodies has a prognostic value. For example, antibodies against topoisomerase I (ATA, Topo I, Scl-70) are more common in patients with dcSSc and they are associated with interstitial lung disease, digital ulcers and hand disability [1]. Anti-centromere antibodies (ACA) occur typically in patients with lcSSc and with a tendency to develop pulmonary hypertension. Antibodies against RNA polymerase III are found in patients with dcSSc and represent a risk factor for renal crisis. They occur in patients with coexisting cancer. Less common are antibodies directed against fibrillarin (anti-U3-RNP) and against Th/To (the antigen is a ribonucleoprotein complex called the human RNase MRP ribonucleoprotein complex with endonuclease properties). The former are more frequently associated with cardiomyopathy, myopathy and pulmonary arterial hypertension, and the latter are typical of patients with lcSSc (Table 4) [31, 32].

\section{INTERSTITIAL LUNG DISEASE}

The diagnostics of pulmonary lesions comprises imaging studies of the lungs such as high resolution computed tomography (HRCT) and pulmonary function tests (PFTs) including forced vital capacity (FVC) and total lung capacity (TLC), as well as diffusing lung capacity for carbon monoxide (DLCO). HRCT makes it possible to establish the diagnosis of interstitial lung disease (ILD) on the basis of ground-glass opacities, linear or reticular shadows at the lung base, interlobular septal thickening, micronodular lesions located peripherally and subpleurally, bronchiectasis and small cysts forming a honeycomb pattern. Ground-glass opacification is typically associated with the early stage of SSc. The stage of lesions found in the initial examination powy indeks ryzyka owrzodzeń skóry (capillaroscopic skin ulcer risk index - CSURI) wyrażony wzorem $M \times D$ : $N^{2}$, gdzie $M$ to liczba megakapilar w $1 \mathrm{~mm}, D$ - najszerszy wymiar megakapilary (bez poszerzenia mikrotętniakowatego), $N$ - liczba pętli naczyniowych w $1 \mathrm{~mm}$. Punkt odcięcia wynosi 2,96. U chorych z wyższymi wartościami wskaźnika występowało istotnie większe ryzyko owrzodzeń paliczków rąk w ciągu 3 miesięcy po badaniu [29]. W badaniu stosuje się kapilaroskop, odpowiednio dostosowany do oceny naczyń mikrokrążenia wału paznokciowego. W wyjątkowych przypadkach (wstępne) badanie kapilaroskopowe może być wykonane przy użyciu dermoskopu ręcznego.

\section{PRZECIWCIAŁA PRZECIWJĄDROWE}

Przeciwciała przeciwjądrowe (antinuclear antibodies - ANA) występują u 90-95\% chorych na SSc. Pacjenci z uogólnionymi stwardnieniami, ale bez krążących przeciwciał przeciwjądrowych wymagają szczegółowej diagnostyki różnicowej w celu wykluczenia chorób twardzinopodobnych [30]. Zazwyczaj u chorych występuje tylko jedno ze swoistych dla choroby autoprzeciwciał. Jest to ważne, bo mają one znaczenie rokownicze: przeciwciała przeciwko topoizomerazie I (ATA, Topo I, Scl-70) częściej występują u chorych na dcSSc i wiążą się z chorobą śródmiąższową płuc, obecnością owrzodzeń paliczków i niepełnosprawnością rąk [1]. Przeciwciała antycentromerowe (ACA) są typowe dla chorych z lcSSc z tendencją do nadciśnienia płucnego. Przeciwciała przeciwko polimerazie III RNA występują u chorych na dcSSc, stanowią czynnik ryzyka przełomu nerkowego i są obecne u osób z towarzyszącym procesem nowotworowym. Do rzadszych autoprzeciwciał należą np. przeciwciała przeciwko fibrylarynie (anty U3-RNP) i przeciwko Th/To (antygenem jest konglomerat rybonukleoproteinowy nazywany kompleksem ludzkiej RNazy MRP o właściwościach endonukleazy). Te pierwsze częściej wiążą się z kardiomiopatią, miopatią i płucnym nadciśnieniem tętniczym, a te drugie są typowe dla chorych na lcSSc (tab. 4) [31, 32].

\section{CHOROBA ŚRÓDMIAŻŻZOWA PŁUC}

Diagnostyka zmian w płucach obejmuje badania obrazowe płuc, w tym tomografię komputerową o wysokiej rozdzielczości (high resolution computed tomography - HRCT), badania czynnościowe (pulmonary function tests - PFTs), w tym natężonej pojemności życiowej (forced vital capacity - FVC) oraz całkowitej pojemności płuc (total lung capacity - TLC), a także badania zdolności dyfuzyjnej płuc dla tlenku węgla (diffusing lung capacity for carbon monoxide - DLCO). Badanie HRCT na podstawie obecności zacienień typu „szkła mleczne- 
Table 4. Antinuclear antibodies in systemic sclerosis

\begin{tabular}{|c|c|c|c|}
\hline ANA & Incidence & Specificity & Potential correlation with clinical features \\
\hline $\begin{array}{l}\text { anti-CENP } \\
\text { ACA }\end{array}$ & $30 \%$ & $97.4 \%$ & pulmonary arterial hypertension (PAH) \\
\hline $\begin{array}{l}\text { anti-Topo I } \\
\text { Scl-70 }\end{array}$ & $40 \%(28-70 \%)$ & $99.8 \%$ (anti-CENP A + B) & $\begin{array}{l}\text { - interstitial lung disease (ILD) } \\
\text { - digital ulcers } \\
\text { - severe/extensive skin lesions }\end{array}$ \\
\hline anti-RNAP I-III & $4-25 \%$ & $99.5 \%$ & $\begin{array}{l}\text { - } \text { severe/extensive skin lesions } \\
\text { - renal crisis } \\
\text { - cancer coexistence }\end{array}$ \\
\hline anti-U3RNP & $4-10 \%$ & 99\% (anti-RNAP III +I) & $\begin{array}{l}\text { - cardiomyopathy } \\
\text { - myopathy } \\
\text { - pulmonary arterial hypertension (PAH) }\end{array}$ \\
\hline anti-Th/To & $2-5 \%(1-13 \%)$ & $96 \%$ & limited skin lesions \\
\hline anti-UII/UI2 RNP & $3 \%$ & relatively specific & \\
\hline
\end{tabular}

Antibodies: ACA, SCl-70 and RNAP I-III are included in the classification criteria for systemic sclerosis.

Tabela 4. Przeciwciała przeciwjądrowe w twardzinie układowej

\begin{tabular}{|c|c|c|c|}
\hline ANA & Częstość występowania & Swoistość & Możliwa korelacja ze zmianami klinicznymi \\
\hline $\begin{array}{l}\text { anty-CENP } \\
\text { ACA }\end{array}$ & $30 \%$ & $97,4 \%$ & nadciśnienie płucne (PAH) \\
\hline $\begin{array}{l}\text { anty-Topo I } \\
\text { Scl-70 }\end{array}$ & $40 \%(28-70 \%)$ & $99,8 \%$ (anty-CENP A + B) & $\begin{array}{l}\text { - choroba środmiąższowa płuc (ILD) } \\
\text { - owrzodzenia paliczków } \\
\text { - nasilone lub rozległe zmiany skórne }\end{array}$ \\
\hline anty-RNAP I-III & $4-25 \%$ & $99,5 \%$ & $\begin{array}{l}\text { - nasilone lub rozległe zmiany skórne } \\
\text { - przełom nerkowy } \\
\text { - współwystępowanie nowotworów }\end{array}$ \\
\hline anty-U3RNP & $4-10 \%$ & $99 \%$ (anty-RNAP III + I) & $\begin{array}{l}\text { - } \text { kardiomiopatia } \\
\text { - } \text { miopatia } \\
\text { - nadciśnienie płucne }(\mathrm{PAH})\end{array}$ \\
\hline anty-Th/To & $2-5 \%(1-13 \%)$ & $96 \%$ & ograniczone zmiany skórne \\
\hline anty-UII/UI2 RNP & $3 \%$ & względnie swoiste & \\
\hline
\end{tabular}

has a prognostic significance [33]. Chest X-ray has insufficient sensitivity and only makes it possible to visualize advanced stage lesions. Screening examinations are based on functional lung tests. According to guidelines of the American Thoracic Society (ATS), normal pulmonary function is defined as FVC $\geq 75 \%$ and TLC $\geq 80 \%$. FVC values $<75 \%$ and TLC $<80 \%$ indicate ILD-associated restrictive disorders. Evaluation of DLCO is based on the single-inspiration method. DLCO evaluates quantitatively the process of gas diffusion through the alveolar-capillary barrier from the pulmonary alveolar space into the blood of pulmonary capillaries [34]. A reduced DLCO value may point to restrictive abnormalities or vascular alterations in pulmonary circulation. Based on the guidelines issued by ATS and the European Respiratory Society (ATS/ERS) the standard value is $\mathrm{DLCO} \mathrm{SB}_{\mathrm{sk}} \geq 80 \%$. In patients with normal baseline values, PFTs and DLCO should be repeated every 6-12 months during a period of 3-5 years go", linijnych lub siateczkowatych zmian przy podstawie płuc, pogrubienia przegród międzyzrazikowych, obecności zmian drobnoguzkowych zlokalizowanych obwodowo i podopłucnowo, rozstrzeni oskrzeli i torbielek tworzących obraz tzw. plastra miodu umożliwia ustalenie rozpoznania choroby śródmiąższowej płuc (interstitial lung disease - ILD). Obraz matowej szyby jest typowy dla wczesnej fazy SSc. Stopień zaawansowania zmian stwierdzanych w pierwszym badaniu ma znaczenie rokownicze [33]. Zdjęcie rentgenowskie klatki piersiowej cechuje się zbyt małą czułością i może uwidocznić dopiero zmiany zaawansowane. Do badań przesiewowych wykorzystuje się badania czynnościowe płuc. Zgodnie z wytycznymi Amerykańskiego Towarzystwa Chorób Klatki Piersiowej (American Thoracic Society - ATS) norma w badaniach czynnościowych to $\mathrm{FVC} \geq 75 \%$ i TLC $\geq 80 \%$. Wartości FVC $<75 \%$ i TLC $<80 \%$ wskazują na zaburzenia typu restrykcyjnego w przebiegu ILD. Ocena DLCO opiera się na metodzie pojedynczego wdechu. Badanie to określa ilościowo 
from disease onset, and afterwards once a year. Patients diagnosed with ILD require monitoring by repeating PFTs and DLCO every 3-4 months. The introduction of therapy should be considered after a marked deterioration in results (decrease in FVC or TLC $\geq 5-10 \%$, or DLCO $\geq 15 \%$, over a period of 3-12 months) [35, 36]. Periodic DLCO assessments, particularly in correlation with HRCT findings or 6-minute walking test, may have a prognostic value [19]. The application of dyspnoea scales, usually the MRC (Medical Research Council) scale, is also recommended [36]. A high risk of ILD development in the early stage of SSc can be identified following the detection of anti-topo I, anti-U3RNP or anti-Th/To antibodies in patients [1].

\section{PULMONARY ARTERIAL HYPERTENSION}

The diagnosis of early-stage pulmonary arterial hypertension $(\mathrm{PAH})$ is extremely difficult, as there are no specific clinical indicators. Initial symptoms usually include dyspnoea, fatigue and exercise intolerance [37]. Pulmonary arterial hypertension develops in $8-13 \%$ of patients with SSc and represents one of the causes of patient death. In 2015, the European Society of Cardiology presented guidelines for the diagnosis of PAH in patients with SSc, which recommend right heart catherization as the golden standard. Non-invasive examinations such as rest and exercise echocardiography, pulmonary function tests or serum concentration of the $N$-terminal fragment of B-type natriuretic peptide (NT-proBNP) should be regarded as screening tests [38]. It seems, however, that an elevated serum concentration of NT-proBNP in combination with reduced DLCO values $(<55 \%)$ can be a marker of increased risk of PAH. Other risk factors include the presence of lcSSc, late-age onset of the disease, fingertip ulcers, reduced capillary density assessed by capillaroscopy, multiple telangiectasias, FVC $<65 \%$, FVC/DLCO $>1.6$, and the presence of anti-ACA antibodies [39-41]. Several algorithms for evaluating patient eligibility for right heart catherization have been suggested. In 2014, Coghlan et al. proposed the DETECT algorithm comprising 8 variables in a two-step decision tree for early detection of $\mathrm{PAH}$. The negative and positive predictive values of the test are claimed to be $98 \%$ and $35 \%$, respectively [42]. Calculations should be performed using a special calculator available online at http:/ / detect-pah. com/ [42, 43].

The examinations presented below are intended for the assessment of organ complications of SSc which are not included in the set of classification criteria, such as the kidneys, gastrointestinal tract, osteoarticular and muscular systems (Table 3 ). proces dyfuzji gazu przez barierę pęcherzykowo-włośniczkową z przestrzeni pęcherzykowej płuc do krwi płucnych naczyń włosowatych [34]. Obniżona wartość DLCO może świadczyć o zmianach typu restrykcyjnego lub zmianach naczyniowych w krążeniu płucnym. Zgodnie z wytycznymi ATS i Europejskiego Towarzystwa Chorób Płuc (European Respiratory Society; ATS/ERS) normą jest DLCO SB sk $_{2} \geq 80 \%$. Przy prawidłowych wynikach badań wyjściowych PFTs i DLCO należy powtarzać co 6-12 miesięcy w ciągu 3-5 lat od początku choroby, a następnie co rok. Kontrola chorych z ILD polega na powtarzaniu PFTs i DLCO co 3-4 miesiące. Terapię należy wdrożyć w razie znaczącego pogorszenia wyników (redukcja FVC lub TLC $\geq 5-10 \%$ lub DLCO $\geq 15 \%$ w ciągu 3-12 miesięcy) $[35,36]$. Okresowa ocena DLCO, zwłaszcza w korelacji z obrazem HRCT lub 6-minutowym testem marszu, może mieć znaczenie rokownicze [19]. Rekomenduje się stosowanie skal nasilenia duszności - najczęściej MRC (Medical Research Council) [36]. Na duże ryzyko pojawienia się ILD we wczesnym okresie SSc wskazuje obecność u chorego przeciwciał anty-topo I, anty-U3RNP lub anty-Th/To [1].

\section{TĘTNICZE NADCIŚNIENIE PŁUCNE}

Rozpoznanie wczesnej fazy tętniczego nadciśnienia płucnego (pulmonary arterial hypertension - PAH) jest niezwykle trudne ze względu na brak swoistych wykładników klinicznych. Najczęściej objawia się ono początkowo dusznością, zmęczeniem i brakiem tolerancji wysiłku [37]. Tętnicze nadciśnienie płucne występuje u $8-13 \%$ chorych na SSc i stanowi jedną z przyczyn zgonu. W 2015 r. Europejskie Towarzystwo Kardiologiczne przedstawiło wytyczne dotyczące diagnostyki PAH u chorych na SSc i rekomenduje cewnikowanie prawego serca jako złoty standard. Badania nieinwazyjne, takie jak echokardiografia spoczynkowa i wysiłkowa, badania czynnościowe płuc lub surowicze stężenie $N$-końcowego fragmentu peptydu natriuretycznego typu B (NT-proBNP), uznaje się za badania przesiewowe [38]. Wydaje się jednak, że podwyższone surowicze stężenie NT-proBNP w połączeniu ze zmniejszonymi wartościami DLCO (<55\%) stanowi marker zwiększonego ryzyka rozwoju PAH. Inne czynniki ryzyka to: obecność lcSSc, początek choroby w starszym wie$\mathrm{ku}$, owrzodzenia na opuszkach palców, zmniejszenie gęstości naczyń w badaniu kapilaroskopowym, liczne teleangiektazje, FVC $<65 \%$, FVC/DLCO > 1,6, obecność przeciwciał anty-ACA [39-41]. Zaproponowano kilka algorytmów kwalifikacji pacjentów do cewnikowania prawego serca. W 2014 r. Coghlan i wsp. przedstawili algorytm DETECT, zawierający 8 zmiennych w dwustopniowym drzewie decyzyjnym, do wczesnego wykrycia PAH. Ujemna wartość predykcyjna testu ma wynosić $98 \%$, a dodatnia 35\% [42]. W celu 


\section{SCLERODERMA RENAL CRISIS}

Renal function should be assessed by regular arterial blood pressure monitoring ( 3 times a week during the initial phase of the disease), $C B C$, serum creatinine concentration, estimated glomerular filtration rate (eGFR), serum renin concentration as well as general urine analysis and 24-hour urine proteinuria. Scleroderma renal crisis (SRC) presents with arterial hypertension, increase in systolic or diastolic blood pressure by $20 \mathrm{~mm} \mathrm{Hg}$, eGFR reduction by $\geq 30 \%$ of normal values, elevated creatinine concentration, haemolysis, increased reticulocyte count, thrombocytopaenia, proteinuria and haematuria. It must be stressed that a small number of SCR cases are not accompanied by elevated blood pressure (so-called normotensive SRC) [44, 45]. Scleroderma renal crisis affects approximately $6 \%$ of all patients with SSc and it is more common in individuals with the dcSSc form (10-15\%), developing usually during the first 3-4 years of disease onset [44]. Approximately half of patients with SRC require dialysis treatment and the mortality rate reaches 10\% [44]. According to the literature data, the 5-year survival rate in SRC patients requiring dialysis therapy is $40 \%$ [44]. A higher risk of SRC is present in patients with antibodies against RNA polymerase III, antitopo I, anti-U3RNP, anti-Th/To [21, 46, 47]. However, the kidneys are more frequently affected by a chronic process characterized by gradual decreases in eGFR, increase in serum creatinine concentration, fairly elevated proteinuria and haematuria, and moderate arterial hypertension [45].

\section{CARDIAC DISEASE}

Routine tests recommended for the diagnosis of cardiac involvement in SSc which, in many cases, may be asymptomatic or present with left ventricular systolic or diastolic dysfunction, arrhythmia or pericarditis, include conventional or 24-hour electrocardiography and echocardiography [48]. ECHO ultrasound examination performed with a standard head for cardiac muscle imaging using 2D and Doppler techniques is applied to evaluate cardiac muscle abnormalities such as cardiac chamber enlargement, valvular activity abnormalities or fluid accumulation in the pericardial cavity, and to measure blood pressure in the pulmonary artery (PAP $\geq 35 \mathrm{~mm} \mathrm{Hg}$ indicates the risk of PAH). Highly beneficial examinations also include NTproBNP testing, because of a correlation between NT-proBNP and the PAP value, and 6-minute walking test [49]. Cardiac examination by magnetic resonance imaging (MRI) is increasingly recommended nowadays [50]. wykonania obliczenia należy skorzystać z kalkulatora dostępnego na stronie http:// detect-pah.com/ [42, 43].

Kolejno omawiane badania służą do oceny powikłań narządowych SSc nieujętych w kryteriach klasyfikacyjnych, w tym nerek, przewodu pokarmowego, serca, układu kostno-stawowego i mięśniowego (tab. 3).

\section{TWARDZINOWY PRZEŁOM NERKOWY}

W ocenie funkcji nerek wykorzystuje się regularną kontrolę ciśnienia tętniczego (we wczesnej fazie choroby 3 razy w tygodniu), morfologii, $w$ tym surowiczego stężenia kreatyniny, wskaźnika filtracji kłębuszkowej (estimated glomerular filtration rate - eGFR), stężenia reniny w surowicy, a także ogólne badanie moczu i białkomoczu w dobowej zbiórce moczu. Pojawienie się nadciśnienia tętniczego, wzrost ciśnienia skurczowego lub rozkurczowego o $20 \mathrm{~mm} \mathrm{Hg}$, zmniejszenie eGFR o $\geq 30 \%$ wartości prawidłowych, wzrost stężenia kreatyniny, hemoliza, zwiększony odsetek retikulocytów, trombocytopenia, białkomocz i krwinkomocz stanowią cechy twardzinowej kryzy nerkowej (scleroderma renal crisis - SRC). Należy podkreślić, że niewielka liczba przypadków SRC przebiega bez wzrostu ciśnienia (tzw. kryza normotensyjna) [44, 45]. Twardzinowa kryza nerkowa dotyka ok. $6 \%$ chorych na SSc, częściej z odmianą dcSSc (10-15\%), u których występuje zwykle w pierwszych 3-4 latach [44]. Około połowa chorych z SRC wymaga dializoterapii, a śmiertelność sięga $10 \%$ [44]. Według piśmiennictwa 5-letnie przeżycie u pacjentów z SRC wymagających dializowania wynosi 40\% [44]. Większe ryzyko wystąpienia SRC występuje $\mathrm{u}$ chorych z przeciwciałami przeciwko polimerazie III RNA, anty-topo I, anty-U3RNP, anty-Th/To [21, 46, 47]. Częściej jednak nerki podlegają procesowi przewlekłemu, którego wykładnikami są stopniowa redukcja wartości eGFR, wzrost surowiczego stężenia kreatyniny, miernie nasilony białkomocz i krwinkomocz oraz umiarkowane nadciśnienie tętnicze [45].

\section{ZMIANY W SERCU}

W celu rozpoznania zajęcia serca w SSc, które w wielu przypadkach może przebiegać bezobjawowo lub objawiać się dysfunkcją skurczową bądź rozkurczową lewej komory, zaburzeniami rytmu, zapaleniem osierdzia, zaleca się rutynowo wykonać badanie elektrokardiograficzne klasyczne lub w zapisie 24-godzinnym oraz badanie echokardiograficzne [48]. W ECHO ze standardową głowicą do badania mięśnia sercowego metodą dwuwymiarową i dopplerowską ocenia się nieprawidłowości w pracy mięśnia sercowego typu: powiększenie jam serca, zmiany w pracy zastawek, obecność płynu w jamie osierdzia, oraz dokonuje się pomiaru ciśnienia $\mathrm{w}$ tętnicy płucnej 


\section{GASTROINTESTINAL DISEASE}

An X-ray examination with contrast is particularly useful for imaging oesophageal lesions. The technique is capable of demonstrating a number of abnormalities such as hypotonia and reduced peristalsis in the lower two-thirds of the oesophagus, loss of longitudinal mucous folds, oesophageal dilatation, abnormalities in the lower oesophageal sphincter, delayed oesophageal emptying in the supine position, gastrointestinal reflux, erosions and superficial ulcers in the lower part of the oesophagus, Barrett's oesophagus presenting as a large and deep ulcer located in the lower oesophagus, Barrett's adenocarcinoma, and gastric atony and dilatation. In the small intestine, an X-ray examination with contrast may reveal features of malabsorption, excessive fluid accumulation due to large intestine dilation and excessive bacterial proliferation, delayed transit time with barium retention in the duodenum for up to 24 hours, marked dilation of the small intestine forming megaduodenum or megajejunum mimicking small intestinal obstruction and false diverticula. In the large intestine, an X-ray examination may visualize features of constipation (also after rectal injection of barium contrast), false diverticula (mainly) in the transverse and descending colon, pronounced dilatation of the large intestine, reduced rectal motility and decreased anal sphincter tone [51, 52]. Endoscopic examination is useful for the diagnosis of inflammatory alterations in the oesophageal mucosa, Barrett's oesophagus and oesophageal strictures [51]. Oesophageal manometry is a test evaluating oesophageal motor disorders. Initially, the test may reveal a decrease in the amplitude of contractions in the distal twothirds of the oesophagus. As the disease progresses, a reduced tension in the lower esophageal sphincter is observed [51]. Oesophageal scintigraphy with oral administration of a technetium-99m labelled agent, followed by the measurement of oesophageal transit time, is a test detecting oesophageal motor disorders such as food retention and gastrointestinal reflux [53]. Ultrasonography is a very sensitive technique for diagnosing primary biliary cirrhosis (PBC) which often accompanies systemic sclerosis, and for evaluating the abdominal cavity in patients with abdominal pain secondary to scleroderma [53]. Oesophageal abnormalities can be assessed by 24hour $\mathrm{pH}$ monitoring in proximal and distal oesophagus. Given the multitude of complaints and symptoms involving the gastrointestinal (GI) tract which are seen in patients with SSc, the recommended screening test is the UCLA SCTC (University of California, Los Angeles Scleroderma Clinical Trial Consortium) GIT 2.0 questionnaire. Based on the
(PAP $\geq 35$ mm Hg wskazuje na możliwość wystąpienia PAH). Bardzo pomocne jest oznaczanie stężenia NT-proBNP, ponieważ stwierdzono korelację między jego wartościami a PAP, oraz wykonanie testu 6-minutowego marszu [49]. Obecnie coraz częściej rekomenduje się badanie serca metodą rezonansu magnetycznego (magnetic resonance imaging - MRI) [50].

\section{DYSFUNKCJA PRZEWODU POKARMOWEGO}

Badanie radiologiczne $\mathrm{z}$ kontrastem jest szczególnie przydatne w obrazowaniu zmian w przełyku. Może wykazać liczne nieprawidłowości, takie jak hipotonia i zmniejszona perystaltyka w dolnych $2 / 3$ przełyku, utrata podłużnych fałdów błony śluzowej, rozszerzenie przełyku, zmiany dolnego zwieracza przełyku, zaburzone opróżnianie przełyku w pozycji leżącej, refluks żołądkowo-jelitowy, nadżerki i powierzchowne owrzodzenia dolnej części przełyku, przełyk Barretta widoczny jako duże i głębokie owrzodzenie w dolnej części przełyku, rak gruczołowy Barretta, atonia żołądka i jego rozszerzenie. $W$ jelicie cienkim badanie radiologiczne $\mathrm{z}$ kontrastem może uwidocznić: cechy złego wchłaniania, nadmiar płynu z powodu rozszerzenia jelita grubego i nadmiernego rozrostu bakterii, opóźniony czas przechodzenia z zaleganiem barytu w dwunastnicy do 24 godzin, znaczne rozszerzenie jelita cienkiego tworzące megaduodenum lub megajejunum naśladujące niedrożność jelita cienkiego oraz pseudouchyłki. W jelicie grubym badanie radiologiczne może ujawnić: cechy zaparcia (także we wlewie doodbytniczym barytu), uchyłki rzekome (głównie) w jelicie poprzecznym i zstępującym, znaczne rozszerzenie jelita grubego, obniżoną motorykę odbytnicy i zmniejszone napięcie zwieracza odbytu [51, 52]. Badanie endoskopowe jest pomocne $\mathrm{w}$ diagnostyce zmian zapalnych błony śluzowej przełyku, rozpoznaniu przełyku Barretta oraz zwężeń przełyku [51]. Manometria wykazuje uszkodzenie czynności motorycznej przełyku. Początkowo badanie może uwidocznić obniżoną amplitudę skurczów w dystalnych 2/3 przełyku, natomiast w dalszym przebiegu choroby obserwuje się zmniejszenie napięcia dolnego zwieracza przełyku [51]. Scyntygrafia przełyku z doustnym zastosowaniem płynu znakowanego technetem $99 \mathrm{mTC}$, a następnie mierzeniem czasu przechodzenia przez przełyk wykrywa zaburzenia motoryki przełyku - zaleganie pokarmu i refluks żołądkowo-jelitowy [53]. Badanie ultrasonograficzne jest bardzo czułą metodą diagnozowania pierwotnej żółciowej marskości wątroby (primary biliary cirrhosis - PBC), często związanej z SSc, a także oceny jamy brzusznej $\mathrm{u}$ pacjentów $\mathrm{z}$ bólami brzucha $\mathrm{w}$ przebiegu twardziny [53]. W badaniu zmian w przełyku zastosowanie ma 24-godzinne monitorowanie $\mathrm{pH}$ proksymalnej i dystalnej części przełyku. Ze względu na mnogość możliwych objawów ze strony przewodu pokarmowego 
questionnaire results, selected additional examinations are performed to evaluate the GI tract section which is affected by the disease [54].

\section{EVALUATION OF OSTEOARTICULAR AND MUSCULAR ABNORMALITIES}

A characteristic manifestation of the disease in joints is articular pain or, less commonly, inflammation involving the metacarpophalangeal joints, wrists, knees, elbows and shoulders, often accompanied by joint contractures. Occasionally, patients develop tendovaginitis, and the characteristic symptom of tendon crepitus occurs. Muscle involvement is manifested by features of myopathy - impairment of muscular strength or, less commonly, signs of myositis. Bone involvement takes the form of distal digit resorption, hyperostosis or osteoporosis. A highly characteristic feature is soft tissue calcinosis, particularly in patients with lcSSc. The standard procedure in the evaluation of osteoarticular and muscular abnormalities is based on radiological and ultrasonographic examinations, tests to detect the rheumatoid factor, antibodies against cyclic citrullinated peptide, creatine kinase level and electromyographic examination [1, 55]. A crucial aspect in the assessment of patients with SSc is determining the duration and activity of the disease, which undoubtedly has an impact on therapeutic decisions [56].

\section{CONFLICT OF INTEREST}

The authors declare no conflict of interest. w SSc rekomenduje się wykorzystanie jako badania przesiewowego kwestionariusza UCLA SCTC (University of California, Los Angeles Scleroderma Clinical Trial Consortium) GIT 2.0. Na jego podstawie dobiera się badania dodatkowe służące do oceny zajętego procesem chorobowym odcinka przewodu pokarmowego [54].

\section{OCENA ZMIAN W UKŁADZIE KOSTNO- -STAWOWYM I MIĘŚNIOWYM}

Charakterystycznym objawem obecności procesu chorobowego w stawach są bóle stawowe, rzadziej zapalenie stawów śródręcznopaliczkowych, nadgarstków, kolan, łokci i barków, często przykurcze w stawach. Niekiedy dochodzi do zapalenia pochewek ścięgnistych i pojawienia się charakterystycznego objawu trzeszczenia ścięgien. Objawy zajęcia mięśni to pojawienie się cech miopatii - osłabienie siły mięśniowej, rzadziej cech zapalenia mięśni. Zajęcie kości polega na resorpcji dystalnych paliczków, obecności hiperostozy lub osteoporozy. Bardzo charakterystyczną cechą jest wapnica tkanek miękkich, zwłaszcza u chorych na lcSSc. Standardowo w ocenie zmian kostno-stawowych i mięśniowych rekomenduje się badania radiologiczne, ultrasonograficzne, badanie obecności czynnika reumatoidalnego, przeciwciał przeciwko cyklicznemu cytrulinowemu peptydowi, stężenia kinazy keratynowej i badanie elektromiograficzne $[1,55]$. W badaniu chorych na SSc ważna jest ocena czasu trwania i aktywności choroby, co niewątpliwie będzie miało wpływ na decyzje terapeutyczne [56].

\section{KONFLIKT INTERESÓW}

Autorzy deklarują brak konfliktu interesów.

\section{References \\ Piśmiennictwo}

1. Denton C.P, Khanna D.: Systemic sclerosis. Lancet 2017, 390, 1685-1699

2. Knobler R., Moinzadeh P., Hunzelmann N., Kreuter A., Cozzio A., Mouthon L., et al.: European Dermatology Forum S1 guideline on the diagnosis and treatment of sclerosing diseases of the skin, Part 1: localized scleroderma, systemic sclerosis and overlap syndromes. J Eur Acad Dermatol Venereol 2017, 31, 1401-1424.

3. Kowal-Bielecka O., Fransen J., Avouac J., Becker M., Kulak A., Allanore Y., et al.: Update of EULAR recommendations for the treatment of systemic sclerosis. Ann Rheum Dis 2017, 76, 1327-1339.

4. Masi A.T., Rodnan G.P., Medsger T.A., Altman R.D., DAngelo W.A., Fries J.F., et al.: Subcommittee for scleroderma criteria of the American Rheumatism Association Diagnostic and Therapeutic Criteria Committee: Preliminary criteria for the classification of systemic sclerosis (scleroderma). Arthrtis Rheum 1980, 23, 581-590.

5. Lonzetti L.S., Joyal F., Raynauld J.P., Roussin A., Goulet J.R., Rich E., et al.: Updating the American College of Rheumatology preliminary classification criteria for systemic sclerosis: addition of severe nailfold capillaroscopy abnormalities markedly increases the sensitivity for limited scleroderma. Arthritis Rheum 2001, 44, 735-736.

6. Walker K.M., Pope J., participating members of the Scleroderma Clinical Trials Consortium (SCTC), Canadian Scleroderma Research Group (CSRG): Treatment of systemic sclerosis complications: what to use when first-line treatment fails: a consensus of systemic sclerosis experts. Semin Arthritis Rheum 2012, 42, 42-55.

7. LeRoy E.C., Medsger T.A. Jr.: Criteria for the classification of early systemic sclerosis. J Rheumatol 2001, 28, 1573-1578.

8. Matucci-Cerinic M., Allanore Y., Czirják L., Tyndall A., Müller-Ladner U., Denton C., et al.: The challenge of early systemic sclerosis for the EULAR Scleroderma Trial and Research group (EUSTAR) community. It is time to cut the Gordian knot and develop a prevention or rescue strategy. Ann Rheum Dis 2009, 68, 1377-1380. 
9. Avouac J., Fransen J., Walker U.A., Riccieri V., Smith V., Muller C., et al.: Preliminary criteria for the very early diagnosis of systemic sclerosis: results of a Delphi Consensus Study from EULAR Scleroderma Trials and Research Group. Ann Rheum Dis 2011, 70, 476-481.

10. Minier T., Guiducci S., Bellando-Randone S., Bruni C., Lepri G., Czirják L., et al.: Preliminary analysis of the Very Early Diagnosis of Systemic Sclerosis (VEDOSS) EUSTAR multicentre study: evidence for puffy fingers as a pivotal sign for suspicion of systemic sclerosis. Ann Rheum Dis 2014, 73, 2087-2093.

11. van den Hoogen F., Khanna D., Fransen J., Johnson S.R., Baron M., Tyndall A., et al.: 2013 classification criteria for systemic sclerosis: an American College of Rheumatology/European League against Rheumatism collaborative initiative. Arthritis Rheum 2013, 65, 2737-2747.

12. Pope J.E., Johnson S.R.: New classification criteria for systemic sclerosis (scleroderma). Rheum Dis Clin North Am 2015, 41, 383-398.

13. Jordan S., Maurer B., Toniolo M., Michel B., Distler O.: Performance of the new ACR/EULAR classification criteria for systemic sclerosis in clinical practice. Rheumatology (Oxford) 2015, 54, 1454-1458.

14. Alhajeri H., Hudson M., Fritzler M., Pope J., Tatibouet S., Markland J., et al.: 2013 American College of Rheumatology/ European League against rheumatism classification criteria for systemic sclerosis outperform the 1980 criteria: data from the Canadian Scleroderma Research Group. Arthritis Care Res (Hoboken) 2015, 67, 582-587.

15. Diab S., Dostrovsky N., Hudson M., Tatibouet S., Fritzler M.J., Baron M., the Canadian Scleroderma Research Group: Systemic sclerosis sine scleroderma: a multicenter study of 1417 subjects. J Rheumatol 2014, 41, 2179-2185.

16. Pakozdi A., Nihtyanova S., Moinzadeh P., Ong V.H., Black C.M., Denton C.P.: Clinical and serological hallmarks of systemic sclerosis overlap syndromes. J Rheumatol 2011, 38, 2406-2409.

17. Foocharoen C., Netwijitpan S., Mahakkanukrauh A., Suwannaroj S., Nanagara R.: Clinical characteristics of scleroderma overlap syndromes: comparisons with pure scleroderma. Int J Rheum Dis 2016, 19, 913-923.

18. Kowal-Bielecka O., Domysławska I., Sierakowski S.: Ocena zmian skórnych u chorych na twardzinę układową: uwagi praktyczne i znaczenie kliniczne. Reumatologia 2005; 43, 310-312.

19. Barsotti B., Stagnaro C., d'Ascanio A., Della Rossa A.: One year in review 2016: systemic sclerosis. Clin Exp Rheumatol 2016, 34 (suppl. 100), S3-S13.

20. Domsic R.T., Nihtyanova S.I., Wisniewski S.R., Fine M.J., Lucas M., Kwoh C.K., et al.: Derivation and validation of a prediction rule for two-year mortality in early diffuse cutaneous systemic sclerosis. Arthritis Rheumatol 2014, 66, 1616-1624.

21. Bellando-Randone S., Guiducci S., Matucci-Cernic M.: Very early diagnosis of systemic sclerosis. Pol Arch Med Wewn 2012, 122 (Suppl 1), 18-23.

22. Spencer-Green G.: Outcomes in primary Raynaud phenomenon: a metaanalysis of the frequency, rates, and predictors of transition to secondary diseases. Arch Intern Med 1998, 158, 595-600.

23. Cutolo M.: Atlas of Capillaroscopy in Rheumatic Diseases. Elservier, Milano, 2010.

24. Herrick A.L., Cutolo M.: Clinical implications from capillaroscopic analysis in patients with Raynaud's phenomenon and systemic sclerosis. Arthritis Rheum 2010, 62, 2595-2604.

25. Cutolo M., Sulli A., Pizzorni C., Accardo S.: Nailfold videocapillaroscopy assessment of microvascular damage in systemic sclerosis. J Rheumatol 2000, 27, 155-160.

26. Caramaschi P., Canestrini S., Martinelli N., Volpe A., Pieropan S., Ferrari M., et al.: Scleroderma patients nailfold videocapillaroscopic patterns are associated with disease subset and disease severity. Rheumatology (Oxford) 2007, 46, 1566-1569.

27. Pucinelli M.L., Atra E., Sato E.I., Andrade L.E.: Nailfold capillaroscopy in systemic sclerosis: correlations with involvement of lung and esophagus. Rev Bras Rheumatol 1995, 35, 136-142.

28. Kayser C., Sekiyama J.Y., Próspero L.C., Camargo C.Z., Andrade L.E.: Nailfold capillaroscopy abnormalities as predictors of mortality in patients with systemic sclerosis. Clin Exp Rheumatol 2013, 31 (2 suppl 76), 103-108.

29. Sebastiani M., Manfredi A., Colaci M., D'amico R., Malagoli V., Giuggioli D., et al.: Capillaroscopic skin ulcer risk index: a new prognostic tool for digital skin ulcer development in systemic sclerosis patients. Arthritis Rheum 2009, 61, 688-694.

30. Knobler R., Moinzadeh P., Hunzelmann N., Kreuter A., Cozzio A., Mouthon L., et al.: European Dermatology Forum S1 guideline on the diagnosis and treatment of sclerosing diseases of the skin, Part 2: Scleromyxedema, scleredema and nephrogenic systemic fibrosis. J Eur Acad Dermatol Venereol 2017, 31, 1581-1594.

31. Hasegawa M.: Biomarkers in systemic sclerosis: their potential to predictclinical courses. J Dermatol 2016, 43, 29-38.

32. Castro S.V., Jimenez S.A.: Biomarkers in systemic sclerosis. Biomark Med 2010, 4, 133-147.

33. Bradley B., Branley H.M., Egan J.J., Greaves M.S., Hansell D.M., Harrison N.K., et al.: British Thoracic Society Interstitial Lung Disease Guideline Group, British Thoracic Society Standards of Care Committee; Thoracic Society of Australia; New Zealand Thoracic Society; Irish Thoracic Society: Interstitial lung disease guideline: the British Thoracic Society in collaboration with the Thoracic Society of Australia and New Zealand and the Irish Thoracic Society. Thorax 2008, 63 (Suppl 5), v1-v58. Erratum in: Thorax 2008, 63, 1029.

34. Piorunek T.: Badanie zdolności dyfuzyjnej płuc dla tlenku węgla (DLCO). Przeg Lek 2007, 1, 55-56.

35. Khanna D., Mittoo S., Aggarwal R., Proudman S.M., Dalbeth N., Matteson E.L., et al.: Connective tissue disease-associated interstitial lung diseases (CTD-ILD) - report from OMERACT CTD-ILD Working Group. J Rheumatol 2015, 42, $2168-2171$

36. Gordon J.K., Domsic R.T.: Clinical trial design issues in systemic sclerosis: an update. Curr Rheumatol Rep 2016, 18, 38.

37. Meune C., Avouac J., Airò P., Beretta L., Dieudé P., Wahbi K., et al.: Prediction of pulmonary hypertension related to systemic sclerosis by an index based on simple clinical observations. Arthritis Rheum 2011, 63, 2790-2796.

38. Galie N., Humbert M., Vachieryc J., Gibbs S., Lang I., Torbicki A., et al.: 2015 ESC/ERS Guidelines for the diagnosis and treatment of pulmonary hypertension. Eur Heart J 2016, 37, 67-119.

39. Allanore Y., Borderie D., Avouac J., Zerkak D., Meune C., Hachulla E., et al.: High N-terminal pro-brain natriuretic peptide levels and low diffusing capacity for carbon monoxide as independent predictors of the occurrence of precapillary pulmonary arterial hypertension in patients with systemic sclerosis. Arthritis Rheum 2008, 58, 284-291.

40. Hassoun M.P.: Lung involvement in systemic sclerosis. Presse Med 2011, 40, e25-e39. 
41. Nihtyanova S.I., Schreiber B.E., Ong V.H., Rosenberg D., Moinzadeh P., Coghlan J.G., et al.: Prediction of pulmonary complications and long-term survival in systemic sclerosis. Arthritis Rheumatol 2014, 66, 1625-1635.

42. Coghlan J.G., Denton C.P., Grünig E., Bonderman D., Distler O., Khanna D., et al.: Evidence-based detection of pulmonary arterial hypertension in systemic sclerosis: the DETECT study. Ann Rheum Dis 2014, 73, 1340-1349.

43. Avouac J., Huscher D., Furst D.E., Opitz C.F., Distler O., Allanore Y., et al.: Expert consensus for performing right heart catheterisation for suspected pulmonary arterial hypertension in systemic sclerosis: a Delphi consensus study with cluster analysis. Ann Rheum Dis 2014, 73, 191-197.

44. Denton C.P., Lapadula G., Mouthon L., Muller-Ladner U.: Renal complications and scleroderma renal crisis. Rheumatology 2009, 48 (Suppl 3), iii32-iii35.

45. Stern E.P., Steen V.D., Denton C.P.: Management of renal involvement in scleroderma. Curr Treat Options Rheum 2015, 1, 106-118.

46. Ioannidis J.P., Vlachoyiannopoulos P.G., Haidich A.B., Medsger T.A. Jr., Lucas M., Michet C.J., et al.: Mortality in systemic sclerosis: an international meta-analysis of individual patient data. Am J Med 2005, 118, 2-10.

47. Lis-Święty A., Brzezińska-Wcisło L.: Twardzina układowa - czynniki prognostyczne, aktywność i ciężkość choroby. Przegl Dermatol 2010, 97, 398-405.

48. Champion H.C.: The heart in scleroderma. Rheum Dis Clin North Am 2008, 34, 181-190.

49. Allanore Y., Meune C.: N-terminal pro brain natriuretic peptide: the new cornerstone of cardiovascular assessment in systemic sclerosis. Clin Exp Rheumatol 2009, 27 (suppl 54), 59-63.

50. Hachulla A.L., Launay D., Gaxotte V., de Groote P., Lamblin N., Devos P., et al.: Cardic magnetic resonance imaging in systemic sclerosis: a cross-sectional observational study of 52 patients. Ann Rheum Dis 2009, 68, 1878-1884.

51. Ebert E.: Esophageal disease in scleroderma. J Clin Gastroenterol 2006, 40, 769-775.

52. Gyger G., Baron M.: Gastrointestinal manifestations of scleroderma: recent progress in evaluation, pathogenesis and management. Curr Rheumatol Rep 2012, 14, 22-29.

53. Kumar S., Singh J., Rattan S., Di Marino A.J., Cohen S., et al.: Review article: pathogenesis and clinical manifestations of gastrointestinal involvement in systemic sclerosis. Aliment Pharmacol Ther 2017, 45, 883-898.

54. Kanna D., Hays R.D., Maranian P., Seibold J.R., Impens A., Mayes M.D., et al.: Reliability and validity ofthe University of California, Los Angeles Scleroderma Clinical Trial Consortium gastrointestinal tract instrument. Arthritis Rheum 2009, 61, 1257-1263.

55. Denton C.P., Hughes M., Gak N., Vila J., Buch M.H., Chakravarty K., et al.: BSR and BHPR guideline for the treatment of systemic sclerosis. Rheumatology (Oxford) 2016, 55, 1906-1910.

56. Valententini G., Della Rossa A., Bombardieri S., Bencivelli W., Silman A.J., D'Angelo S., et al.: European multicentre study to define disease activity criteria for systemic sclerosis. II. Identification of disease activity variables and development of preliminary activity indexes. Ann Rheum Dis 2001, 60, 592-598.

Received: 29.09 .2017

Accepted: 9.10 .2017

Otrzymano: $29.09 .2017 \mathrm{r}$

Zaakceptowano: $9.10 .2017 \mathrm{r}$

How to cite this article

Krasowska D., Rudnicka L., Dańczak-Pazdrowska A., Chodorowska G., Woźniacka A., Lis-Święty A., Czuwara J., Maj J., Majewski S., Sysa-Jędrzejowska A., Wojas-Pelc A.: Systemic sclerosis - diagnostic and therapeutic recommendations of the Polish Dermatological Society. Part 1: diagnosis and monitoring. Dermatol Rev/Przegl Dermatol 2017, 104, 483-498. DOI: https:/ / doi. org/10.5114/dr.2017.71214. 